\section{Studia \\ z Filologii Polskiej i Słowiańskiej}

Studia z Filologii Polskiej i Słowiańskiej, 54

Warszawa 2019

Article No. 2048

DOI: $10.11649 /$ sfps.2048

Citation:

Genew-Puhalewa, I. (2019). Rejestry w bułgarskim dyskursie dziennikarskim. Rec.: Андреана Ефтимова, Регистри вжурналистическия дискурс, Университетско издателство „Св. Климент Охридски”, София 2018, 244 ss. Studia z Filologii Polskiej i Słowiańskiej, 54. https://doi.org/10.11649/sfps.2048

Genew-Puhalewa, I. (2019). Rejestry w bułgarskim dyskursie dziennikarskim. Rec.: Andreana Eftimova, Registri v zhurnalisticheskiia diskurs, Universitetsko izdatelstvo "Sv. Kliment Okhridski”, Sofiia, 2018, 244 ss. Studia z Filologii Polskiej i Słowiańskiej, 54. https:// doi.org/10.11649/sfps.2048

\title{
Rejestry w bułgarskim dyskursie dziennikarskim. Rec.: Андреана Ефтимова, Регистри в журналистическия дискурс, Университетско издателство „Св. Климент Охридски”, София 2018, 244 ss.
}

Monografia Andreany Eftimowej pt. Rejestry $w$ dyskursie dziennikarskim (Ефтимова, 2018) ukazała się w 2018 roku nakładem Wydawnictwa Uniwersytetu Sofijskiego im. Św. Klemensa z Ochrydy. Wypełnia ona istotną lukę w lingwistyce bułgarskiej. Na wcześniejszy dorobek Eftimowej składają się książki równie ważne dla medialingwistów i szerzej - zainteresowanych problematyką języka i komunikacji, jak np. Język i styl mediów: teoria i wspótczesne praktyki (Ефтимова, 2014) czy Podwójny język mediów. Polityczna poprawność contra mowa nienawiści (Ефтимова, 2017). Badaczka w nowej książce kontynuuje swoje dotychczasowe dociekania, zastanawia się w niej bowiem nad pojęciem rejestru w odniesieniu do badań nad dyskursem dziennikarskim. Jest to przedsięwzięcie ambitne, gdyż wymagało od autorki przeciwstawienia się pewnej tradycji w obrębie bułgarskiej stylistyki i socjolingwistyki.

Monografia składa się ze wstępu, ośmiu rozdziałów, zakończenia, bibliografii oraz aneksu, zawierającego karty ankietowe, skrypty dyskusji telewi-

This is an Open Access article distributed under the terms of the Creative Commons Attribution 3.0 PL License (creativecommons.org/licenses/by/3.0/pl/), which permits redistribution, commercial and non-commercial, provided that the article is properly cited. (c) The Author(s) 2019.

Publisher: Institute of Slavic Studies, Polish Academy of Sciences

[Wydawca: Instytut Slawistyki Polskiej Akademii Nauk] 
zyjnych i fotografie materiałów prasowych. We wstępie (Ефтимова, 2018, ss. 7-10) Eftimowa motywuje konieczność uporządkowania wiedzy o rejestrze wobec mnogości ujęć tego pojęcia, a także wobec jego wciąż nieustabilizowanej pozycji w systemie terminów i definicji, opisujących funkcjonowanie różnych odmian języka w poszczególnych sferach życia społecznego. Autorka podkreśla, że na gruncie bułgarskim rejestr zderzył się z aktualnym, skądinąd spójnym, paradygmatem naukowym, będąc pojęciem i terminem „zaimportowanym” $\mathrm{z}$ anglojęzycznej literatury socjolingwistycznej, pojęciem jednak potrzebnym $\mathrm{z}$ uwagi na nieustanne komplikowanie się współczesnej komunikacji. W pierwszym rozdziale monografii dokonano zatem próby redefiniowania i rozgraniczenia pojęć: rejestr, styl, socjolekt, dialekt, gatunek z odpowiednim odwołaniem się do prac autorów zagranicznych (w tym Teuna van Dijka, Michaela A. K. Hallidaya, Richarda A. Hudsona, Janet Holmes, Charlesa A. Fergusona, ale też Stanisława Grabiasa) i bułgarskich (w tym Michaiła Widenowa, Stefany Dimitrowej i in.).

Drugi rozdział rozpoczyna prezentacja własnych poglądów autorki odnośnie do rejestru (Ефтимова, 2018, s. 33), a mianowicie: 1) pojęcie rejestr ma węższy zakres niż pojęcie styl, przy czym realizuje się w jego ramach lub „wędruje” między (kilkoma) stylami; 2) rejestr jest rezultatem kombinacji wpływów konkretnych czynników sytuacyjnych i selekcji konkretnych środków wyrażania różnorodnych relacji społecznych i personalnych;3) liczba rejestrów przewyższa liczbę stylów. Następnie przedstawiono różne typologie podstawowych rejestrów, oparte na powiązaniu środków werbalnych i niewerbalnych z cechami sytuacyjnymi w komunikacji.

Wyjściowe dla badań Andreany Eftimowej tezy, że 1) media i dziennikarstwo to obszary, w których współistnieją wszystkie odmiany językowe danej wspólnoty komunikacyjnej; 2) pisane i ustne teksty dziennikarskie stanowią jeden z obszarów realizacji rejestrów, znajdują w monografii swoje rozwinięcie i odpowiednią solidną argumentację w kolejnych rozdziałach. Metoda badawcza analizy ramowej, obejmująca analizę stylistyczną, procedury eksperymentalne, ankietę, analizę pragmatyczną i inne, została zastosowana na konkretnych tekstach dziennikarskich w celu zinwentaryzowania środków werbalnych i niewerbalnych, lingwistycznych i sytuacyjnych, które ostatecznie pozwoli na zidentyfikowanie poszczególnych rodzajów rejestrów. W połączeniu samodzielnych analiz z interpretacją, opartą na współczesnych koncepcjach lingwistycznych i komunikologicznych, tkwi szczególna wartość książki Eftimowej, której ponadto udało się: 1) postawić problem postrzegania mowy dziennikarskiej jako 
wzoru mowy prestiżowej, za którym stoją przewartościowanie i nowe postawy wobec publicznych zachowań słownych Bułgarów; 2) rozstrzygnąć dyskusyjną kwestię przynależności tekstów pisanych i ustnych w sferze publicznej do jednego rejestru - badaczka dowodzi możliwość takiej przynależności; 3) dać definitywną odpowiedź na pytanie, czy gatunek (jego zmiana) ma wpływ na przynależność tekstu do określonego rejestru - jest ona negatywna; 4) dokonać próby rozróżnienia cech i znaczników stylów oraz rejestrów; 5) określić wzajemne relacje rejestrów według wybranej cechy sytuacyjnej (np. rejestrów oficjalnych/nieformalnych, pisanych/ustnych) z innymi rejestrami według innej cechy (np. rejestr moralizatorski czy potoczny); wyodrębnić, odpowiednio nazwać i scharakteryzować specyficzne dla współczesnej Bułgarii typy rejestrów politycznych: брюкселски новоговор (nowomowa brukselska) oraz популистки регистьр (rejestr populistyczny).

Będąc pierwszym kompleksowym ujęciem problemu rejestrów w dyskursie dziennikarskim na gruncie bułgarskim, monografia Andreany Eftimowej stanowi ważną pozycję dla bułgarystów i slawistów, a także dla czytających po bułgarsku stylistyków, medialingwistów i komunikologów.

\section{Bibliografia}

Ефтимова, А. (2014). Медиен език и стил: теория и съвременни практики. София: Университетско издателство „Св. Климент Охридски”.

Ефтимова, А. (2017). Двойственият език в медиите: езикът на политическата коректност vs езика на омразата. София: Просвета.

Ефтимова, А. (2018). Регистри в журналистическия дискурс. София: Университетско издателство „Св. Климент Охридски”.

\section{Bibliography (Transliteration)}

Eftimova, A. (2014). Medien ezik i stil: teoriia i sŭvremenni praktiki. Sofiia: Universitetsko izdatelstvo "Sv. Kliment Okhridski".

Eftimova, A. (2017). Dvoǔstveniiat ezik v mediite: ezikŭt na politicheskata korektnost vs ezika na omrazata. Sofiia: Prosveta.

Eftimova, A. (2018). Registry v zhurnalisticheskiia diskurs. Sofiia: Universitetsko izdatelstvo "Sv. Kliment Okhridski". 


\title{
Registers in Bulgarian Journalist Discouse. Review: Andreana Eftimova, Registri $v$ zhurnalisticheskiia diskurs, Universitetsko izdatelstvo “Sv. Kliment Okhridski”, Sofiia 2018, 244 pp.
}

\author{
Summary
}

The article is a review of Andreana Eftimova's study Registri v zhurnalisticheskiia diskurs [Registers in Journalistic Discourse].

\section{Rejestry w bułgarskim dyskursie dziennikarskim. Rec.: Андреана Ефтимова, Регистри в журналистическия дискурс, Университетско издателство „Св. Климент Охридски”, София 2018, 244 ss.}

\section{Streszczenie}

Artykuł stanowi recenzję pracy Andreany Eftimowej Регистри в журналистическия дискурс [Rejestry w dyskursie dziennikarskim].

Keywords: review; Bulgarian language; stylistics; language of the media

Słowa kluczowe: recenzja; język bułgarski; stylistyka; język mediów

\footnotetext{
Iliana Genew-Puhalewa, University of Warsaw, Warsaw

ORCID: https://orcid.org/0000-0002-1780-166X

Correspondence: ilianag@interia.pl

The preparation of this article was financed within the statutory activity of the Institute of Western and Southern Slavic Studies, University of Warsaw.

Competing interests: The author declares that she has no competing interests.
} 